\title{
Broken genes in solid tumours
}

\section{肺がんの原因となる融合遺伝子}

Matthew Meyerson

2 つの遺伝子の一部が融合して雑種遺伝子を形成するような変異は、血液関連のがんで多くみら れる。こうした融合遺伝子の 1 つが、最も広くみられる種類の肺がんにかかわつていることが、 新しい知見から明らかになった。

Nature vol.448 (545-546)/2 August 2007

肺がんは、世界中のがんによる死亡者数の第一位を 占めて抢り 1 、肺がんによる年間の死亡者数は 100 万 人を超える。非小細胞肺がん（NSCLC）は、肺がん の全症例の抢上そ $80 \%$ を占める。Nature 2007 年 8 月 2 日号で曽田たち ${ }^{2}$ は、ヒトの NSCLCに関係する 遺伝子を発見して報告している。彼らは、第 2 染色 体短腕（2p）上にある遺伝子の再配列による変異が、 ALK チロシンキナーゼをコードする遺伝子 $A L K$ の発 現を活性化させることを見つけた。チロシンキナーゼ は、ほかのタンパク質のチロシン・アミノ酸残基にリ ン酸基を付加することで、そのタンパク質の活性を調 節する「分子スイッチ」である。これらの酵素は多く のがんに関係があるとみられており、そのため、染色 体再配列をもつがん患者に対する治療法として、ALK キナーゼの活性の阻害が威力を発揮するのではない かと考光られる。

実際、活性化したがん遺伝子 (がん関連遺伝子) の タンパク質産物を阻害することは、がん治療における 有効な戦略の 1 つとつており 3 、研究初期には、醳 素によるチロシンキナーゼの阻害による成功例が多い。 例えば、ABL チロシンキナーゼを活性化する染色体再 配列によって引き起こされる慢性骨髄性白血病 ${ }^{4}$ では、 チロシンキナーゼ阻害㓮であるイマチニブ (グリベッ ク）により患者の生存期間を延長することができる ${ }^{5}$ 。

しかし、どんな種類のがんであっても、がんの成長 と生存を支える複数のがん遺伝子のうち一部のものし
か特定されていないため、遺伝子を標的とする治療戦 略の応用には限りがあった。そのうえ、遺伝子機能を 破壊する治療戦略が、既知のがん遺伝子だからといつ て必ずしも使えるとは限らない。したがって、曽田た ちが今回、ありふれたがんの原因となる新しいがん遺 伝子を発見し、しかも、このがん遺伝子の産物の分子 構造から酵素による阻害を受けやすいことも見つけた のは、画期的な成果である。

曽田たち ${ }^{2}$ は、喫煙歴をもつ NSCLC 患者 1 名から 肺の組織標本を採取し、全メッセンジャーRNA プー ルを抽出して、mRNA 転写産物に相補的な DNA 配列 のライブラリーを作成し、増幅した。次に、従来の形 質転換アッセイを使って、この相補的 DNA 配列のが 几遺伝子活性を解析した。マウスの 3T3 繊維芽細胞を 形質転換させる可能性のある遺伝子、つまり、その遺 伝子の発現によって 3T3 瀻維芽細胞が腫瘍細胞に特有 の性質をもつょうになる遺伝子を探したのである。そ れまで、いくつかの研究グループが同じようなスクリー ニング法を試みていたが、今回ほどめざましい結果を 得たグループはほとんぞなかった。そのため、この方 法の成功は技術上の偉業といえるものだった。

曽田たちは、3T3 細胞を形質転換させうる塩基配列 として、1つの融合 mRNA 転写産物に由来する相補的 DNA 配列を特定した。この塩基配列の最初の部分は、 $E M L 4$ 遺伝子の一部からなっており、そ机に続く部分 は $A L K$ 遺伝子の一部からなっていた。もともと $A L K$ 
遺伝子は、血液由来のがんの一種である未分化大細胞 リンパ腫に関与する遺伝子として見つかったものであ る ${ }^{6}$ 。したがつて、肺がんでこの遺伝子の活性化が見 つかったことは驚きである2。

大部分の NSCLC、とりわけ組織標本検査で最もよ くみられる肺腺がんは、EGFR や Erbb2 などの受容 体チロシンキナーゼやそれらの下流の Ras や Raf がん 遺伝子が介在する分子シグナル伝達経路の活性化を必 要とする7。そのため、活性化された ALK は EGFR/ Erbb2 と同じく、Ras-Raf シグナル伝達経路のスイッ チを構成的にオンにする可能性があると考えてよさそ うである（図 1)。

曽田たちは次に、日本人の NSCLC 患者でEML4$A L K$ 融合遺伝子の保有率を調べたところ、調查した 75 名の患者のうち 5 名が保有していた。ほかの患者集 団における $A L K$ 再配列の保有率はまだ不明だが、重要 な問題である。というのは、同じくNSCLCにつなが る 2 つのかの変異（EGFR と K-RAS にある）の保有 率は、民族間で差があるからだ。東アジアの NSCLC 患者のうち、およそ $40 \%$ が EGFR 変異を保有しており、 $10 \%$ がK-RAS 変異を保有している。ところが、欧州や 北米では、EGFR 変異を保有しているのはNSCLC 患 者のおよそ10\%にすぎず、患者の約 $25 \%$ では K-RAS がん遺伝子が変異している。曽田たちが調べた小規 模な症例群では、ALKの変異をもつ集団と K-RASや EGFR の変異をもつ集団はまったく重ならなかった。

これまでのところ、肺がんに有効な標的治療薬と しては、チロシンキナーゼ阻害剤であるゲフィチニ ブ (イレッサ) やエルロチニブ (タルセバ) しかない。 これらは多くの国で認可されており、EGFR変異をも つ NSCLC 患者の治療用には最も有効だとみられてい $3^{8-10}$ 。曽田たちは、ALK の阻害が生理学的に実現可 能なことを示す証拠を提示し、EML4-ALK 融合遺伝子 で形質転換したマウス BA/F3 細胞を、ALK 阻害剤で 特異的に殺傷できることを示した。もし EML4-ALK 融 合が喫煙歴のある NSCLC 患者において高頻度で見つ か机ば、こうした阻害剤の臨床使用の可能性に対して 特に関心が集まることだろう。ゲフィチニブやエルロチ ニブが最も有効な対象は、ほぼ確実に EGFR 変異によ る腫瘍をもつ喫煙歴のない NSCLC 患者だからである。 最近まで、染色体再配列は主に血液関連のがん と関連づけられており、固形腫瘍との関連はほとん ど考えられていなかった。しかし、前立腺がんでは TMPRSS2-ERG 融合遺伝子や TMPRSS2-ETV1 融合遺 伝子が発見され ${ }^{11,12}$ 、今回さらに $E M L 4-A L K$ 融合遺伝 子の肺がんへの関与が示唆された。これらのことより、

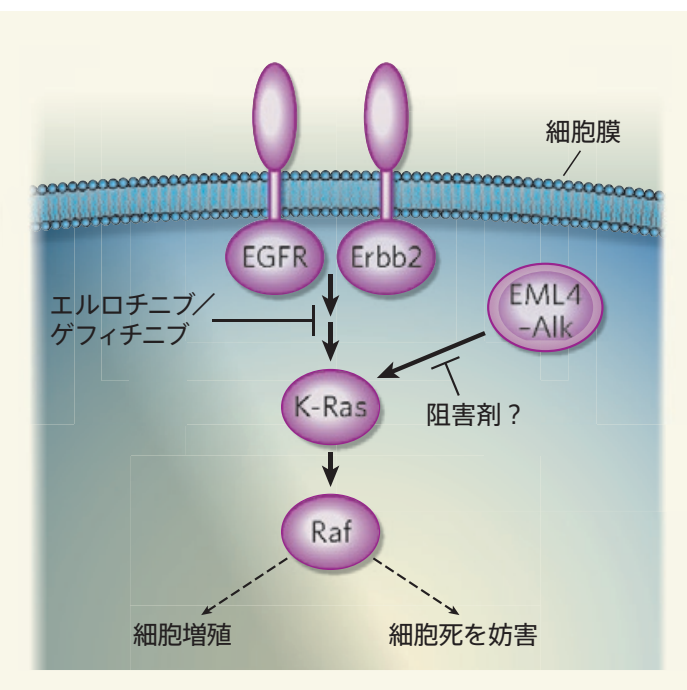

図 1 EML4-ALK 融合タンパク質と肺がん。EGFR と Erbb2 という 2 種類のチロシンキナーゼの変異は、これ らの受容体の下流にあるシグナル伝達分子 (Ras と Raf) の変異とともに、非小細胞肺がん（NSCLC）に関連する ことが既にわかっている。これらの变異タンパク質は、 がん細胞の增殖を促進したり、がん細胞のプログラム細 胞死を妨げたりすると考えられている。曽田たち ${ }^{2}$ は、 NSCLC の一部の症例では染色体再配列によって、EML4ALK 融合タンパク質を作り出す融合遺伝子が生じている ことを見いだした。この融合タンパク質も活性型チロシン キナーゼとして機能するので、EGFR 介在型のシグナル伝 達経路を促進させる可能性がある。エルロチニブやゲフィ チニブといったチロシンキナーゼ阻害剤は、NSCLC の有 効な治療薬であることから、EML4-ALK の阻害剤もこの がんの治療薬として同じく有望だと考えられる。

染色体再配列で生じる活性型の融合遺伝子はおそらく、 固形腫揚において一般的かつ重要なものだと考元られ る。こうした遺伝子融合をゲノム規模で系統的に見つ けだす方法や、そ机らの遺伝子融合情報を利用して診 断する方法を開発することで、固形腫瘍の発生機構の 解明に向けて一歩前進することができるだろう。

Matthew Meyerson、ダナ・ファーバーがん研究所 (米)

1. Parkin, D. M., Bray, F., Ferlay, J. \& Pisani P. CA Cancer J. Clin. 55, 74-108 (2005).

2. Soda, M. et al. Nature $448,561-566$ (2007).

3. Sawyers, C. Nature 432, 294-297 (2004).

4. de Klein, A. et al. Nature 300, 765-767 (1982)

5. Druker, B. J. et al. N. Engl. J. Med. 344, 1031-1037 (2001)

6. Morris, S. W. et al. Science 263, 1281-1284 (1994).

7. Sharma, S. V., Bell, D. W., Settleman, J. \& Haber D. A. Nature Rev. Cancer 7, 169-181 (2007).

8. Lynch, T. J. etal. N. Engl. J. Med. 350, 2129-2139 (2004).

9. Paez, J. G. et al. Science 304, 1497-1500 (2004).

10. Pao, W. et al. Proc. Natl Acad. Sci. USA 101,13306-13311 (2004)

11. Tomlins, S. A. et al. Science 310, 644-648 (2005).

12. Tomlins, S. A. et al. Nature 448, 595-599 (2007). 